\title{
Globalisation, EU expansion and consequences for MNE location
}

Citation for published version (APA):

Narula, R. (2005). Globalisation, EU expansion and consequences for MNE location. MERIT, Maastricht Economic Research Institute on Innovation and Technology. MERIT-Infonomics Research Memorandum Series No. 003 https://doi.org/10.26481/umamer.2005003

Document status and date:

Published: 01/01/2005

DOI:

10.26481/umamer.2005003

Document Version:

Publisher's PDF, also known as Version of record

\section{Please check the document version of this publication:}

- A submitted manuscript is the version of the article upon submission and before peer-review. There can be important differences between the submitted version and the official published version of record.

People interested in the research are advised to contact the author for the final version of the publication, or visit the DOI to the publisher's website.

- The final author version and the galley proof are versions of the publication after peer review.

- The final published version features the final layout of the paper including the volume, issue and page numbers.

Link to publication

\footnotetext{
General rights rights.

- You may freely distribute the URL identifying the publication in the public portal. please follow below link for the End User Agreement:

www.umlib.nl/taverne-license

Take down policy

If you believe that this document breaches copyright please contact us at:

repository@maastrichtuniversity.nl

providing details and we will investigate your claim.
}

Copyright and moral rights for the publications made accessible in the public portal are retained by the authors and/or other copyright owners and it is a condition of accessing publications that users recognise and abide by the legal requirements associated with these

- Users may download and print one copy of any publication from the public portal for the purpose of private study or research.

- You may not further distribute the material or use it for any profit-making activity or commercial gain

If the publication is distributed under the terms of Article $25 \mathrm{fa}$ of the Dutch Copyright Act, indicated by the "Taverne" license above, 


\section{MERIT-Infonomics Research Memorandum series}

Globalisation, EU expansion and consequences for MNE location

\section{Rajneesh Narula}

2005-003

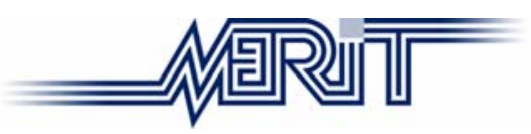

MERIT - Maastricht Economic Research Institute on Innovation and Technology

PO Box 616

6200 MD Maastricht

The Netherlands

T: +31433883875

F: +31433884905

http://www.merit.unimaas.nl

e-mail:secr-merit@merit.unimaas.nl

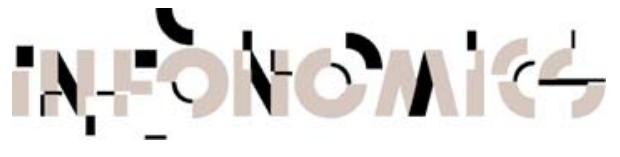

International Institute of Infonomics

c/o Maastricht University

PO Box 616

6200 MD Maastricht

The Netherlands

T: +31433883875

F: +31453884905

http://www.infonomics.nl e-mail: secr@infonomics.nl 


\title{
Globalisation, EU expansion and consequences for MNE location
}

\author{
Rajneesh Narula \\ University of Reading
}

\begin{abstract}
:
Many of the EU accession countries are confident that membership will result in substantially increased inward foreign direct investment (FDI). At the same time, other peripheral EU members (such as Spain and Portugal) are concerned that FDI will be displaced to these new countries. I postulate that the new members cannot expect the same increased FDI flows that resulted to earlier EU entrants. Both groups of countries cannot base their industrial development strategy on passive reliance on such flows. Reliance on low costs and other 'generic' advantages such as basic infrastructure is myopic in a globalised world. Benefiting from FDI requires a comprehensive strategy to build up domestic absorptive capacity and upgrading of the quality of their location advantages, since they are faced with increased competition for FDI not just from other European countries but also from other parts of the world, most notably Asia.
\end{abstract}

Keywords: FDI, EU, multinationals, absorptive capacity, Spain, globalisation, development, enlargement

JEL classification: F02, F23, O14, O19

I do not think it is an exaggeration that policy makers in most European countries seem to consider inward foreign direct investment (FDI) as an indispensable part of their industrial development strategy. This is especially the case in the smaller, less economically developed, more 'peripheral' economies of the EU, such as Greece, Spain, Portugal, Ireland (referred to here as the 'cohesion' countries) as well as the candidate and accession countries of central and eastern Europe (CEE). This paper will discuss the changing role of FDI in these countries, particularly in terms of the costs, benefits, opportunities and limitations of an FDI-driven industrial development strategy. I will focus on discussing the policy issues and challenges that face these countries. The two groups are closely related: The CEE countries look to duplicate the benefits that have accrued to Spain, Portugal and Ireland from FDI. The cohesion countries, on the other hand are concerned that EU enlargement will result in a certain amount of displacement of FDI as their comparative advantage within the EU as lowcost locations is usurped by the CEE countries. 


\section{Some stylised facts about FDI-assisted development strategies FDI}

Although inward FDI does not represent the only option available to promote economic catching-up, it may represent the most efficient option (Dunning and Narula 2004). FDI, however, is not a sine qua non for development. There are three other conditions that need to be satisfied:

1. Does the kind of FDI being attracted generate significant spillovers?

2. Does the domestic sector have the capacity to absorb these spillovers?

3. Is the FDI that is being attracted, a substitute or complementary to domestic industry?

It is true that the determinants of economic development are similar to the determinants of FDI, but this does not mean that there is a simple cause and effect between them. Particular types of FDI tend to be attracted to countries with certain levels of economic development and appropriate economic structures. But simply to 'pump' a country full of FDI will not catapult it to a higher stage of development.

I will highlight two points here. The first is that FDI without the appropriate domestic absorptive capacity, even if it were to be attracted through large subsidies is unlikely to become embedded, or provide significant externalities and spillovers to the host economy.

Second, not all FDI is equal in the nature of the benefits it provides. The quality of the spillovers that derive from an investment are associated with the scope and competence level of the subsidiary, and these are co-determined by a variety of factors. These include MNE internal factors such as their internationalization strategy, the role of the new location in their global portfolio of subsidiaries, and the motivation of their investment are pivotal in the structure of their investment, in addition to the available location-specific resources which can be used for that purpose (Benito et al 2003). High competence levels require complementary assets that are non-generic in nature, and are often associated with agglomeration effects, clusters, and the presence of highly specialized skills. In other words, firms are constrained in their choice of high competence subsidiaries by resource availability. For instance, R\&D activities tend to be concentrated in a few locations because the appropriate specialized resources are associated with a few specific locations. The embeddedness of firms is often (but not always) a function of how long the MNEs 
have been present, since firms tend to build incrementally. MNEs build on location advantages that already exist in the host economy, and increases in embeddedness are generally in response to improvements in the domestic technological capacity. However, while the scope of activities undertaken by a subsidiary can be modified more or less instantly, developing competence levels takes time. MNE investments in high value-added activities (often associated with high competence levels) have the tendency to be 'sticky'. Blomstrom and Kokko (1997) suggest that some of the host country characteristics that may influence the extent of linkages - and thereby in the longer term the extent of spillovers - are market size, local content regulations and the size and technological capability of local firms. They argue that there is a propensity for linkages to increase over time, as the skill level of local entrepreneurs grows, new suppliers emerge and local content increases.

MNEs are unwitting development tools: their primary objective is to generate profits. They do not provide opportunities for development because they are philanthropic; they do so because they need to do so to optimize their profit making potential. MNEs seek to optimise their return on investment, and this logically requires that they minimize their costs. MNEs do not make investment decisions lightly, or without consideration of the benefits. MNEs are creatures of the market par excellence, responding efficiently to supply and demand conditions, and changes in these. They do not make such investments unless there is an opportunity for rent-seeking.

MNEs do not make available their proprietary assets available at the whims of governments; rather they tailor their investment decisions to the existing market needs, and the relative quality of location advantages, but especially the skills, capabilities and infrastructure in which the domestic economy has a comparative advantage. It is also clear that the kind of FDI activity a country might attract (or wish to attract), too, at different stages of development, are different (Dunning and Narula 1996, 2004). The motive of the investment is crucial in determining the extent to which linkages and externalities develop. The motive of an investment helps to determine (in conjunction with the host-country specific factors) the kind of MNE affiliate and therefore the potential for spillovers. It is generally acknowledged that there are four main motives for investment: 1) to seek natural resources; 2) to seek new markets; 3 ) to restructure existing foreign production through rationalization and 4) to seek strategically related created assets. These in turn can be broadly divided into two types. The first three represent motives which are primarily asset-exploiting 
in nature: that is, the investing company's primary purpose is to generate economic rent through the use of its existing firm-specific assets. The last is a case of assetaugmenting activity, whereby the firm wishes to acquire additional assets which protect or augment their existing created assets in some way. In general, developing countries are unlikely to attract much asset-augmenting FDI, but tend to receive FDI that is primarily resource-seeking, market-seeking or efficiency seeking. The relative importance of each is a function of the stage of economic development which itself is a function of the quality of its absorptive capacity (Narula 2004).

The point here is that not all affiliates provide the same opportunity for spillovers. A sales office may have a high turnover, employ a large staff, but the technological spillovers will be relatively fewer than, say, a manufacturing facility. Likewise, resource-seeking activities, can be capital intensive, but also provide fewer spillovers than say, a market-seeking type of FDI. Prior to economic liberalization and EU integration, MNEs responded to investment opportunities primarily by establishing miniature replicas of their facilities at home, although the extent to which they are truncated varied considerably between countries. The extent of truncation was determined by a number of factors, but by far the most important determinant of truncation- and thereby the scope of activities and competence level of the subsidiary - were associated with market size, and capacity and capability of domestic industry (Dunning and Narula 2004). There is thus a hierarchy of the quality of FDI activity in Europe which reflects the stage of industrial development. At the 'bottom', CEE countries without a domestic sector and with low demand have been host to the most truncated subsidiaries, often to the point of being single-activity subsidiaries. Activities were primarily in sales and marketing, and natural resource extraction. The most advanced economies with domestic technological capacity (such as the core EU members) have hosted the least truncated subsidiaries, often with R\&D departments. Cohesion countries (with the exception of Greece) have been in the middle.

The CEE countries will not necessarily benefit from an increase in the quality of FDI that they receive because of EU membership. Although there will be some investment in new affiliates resulting in new (greenfield) subsidiaries that did not exist previously, there will also be a downgrading of subsidiaries. MNEs may divest their operations in response to better location advantages elsewhere in the EU (as Spain and Portugal are now experiencing as their low cost advantages are eroded), or reduce the intensity of operations by lowering the level of competence and/or scope of their 
subsidiary, and shifting from truncated replicas to single activity affiliates. There may also be redistribution effect. That is, sectors that were dominated by domestic capital were transferred to foreign ownership. This has also, in many cases, led to a downgrading of activities from truncated replica to single activity affiliates.

MNEs have taken advantage of the EU single market to rationalise production capacity in fewer locations to exploit economies of scale, especially where local consumption patterns are not radically different to justify local capacity and where transportation costs are not prohibitive. This has meant that some miniature replicas have been downgraded to sales and marketing affiliates, which can be expected to have fewer opportunities for spillovers. It is ironic that the countries that receive the kinds of FDI that has the highest potential benefits vis-à-vis industrial development are those that already have a highly developed domestic absorptive capacity.

In other words, domestic capacity - whether in the form of knowledge infrastructure or efficient domestic industrial sector - is a primary determinant of high competence foreign affiliates. Some countries have succeeded in attracting such FDI, notably Ireland.

By focusing on promoting and attracting MNEs as the primary aspect of their industrial development strategy, many countries neglect the need to promote their domestic sector. If no domestic sector were to exist there can be no opportunity to absorb spillovers from FDI: In a perfectly liberalised world, MNEs have no incentive to encourage the development of domestic firms to meet their needs since they can do so using either imports or FDI. In an extreme case, there may actually be no FDI inflow, because MNEs will prefer to locate production in a regionally optimal location and simply import. The benefits of FDI only occur when there is domestic investment, and where the domestic investment has the ability to internalise the externalities from FDI.

\section{Over-estimating the effect of EU membership on FDI inflows}

EU membership per se does not necessarily lead to an increase in the quality or the quantity of FDI that a country will receive. This is best illustrated by the case of Greece. In 1980, inward FDI stock was \$ 5.5 billion compared with \$3.6 billion and $\$ 5.4$ billion in Portugal and Spain. By 2003, FDI stock in Greece had grown to only 
\$17 billion, compared with \$53 billion and \$ 230 billion for Portugal and Spain respectively.

It is important to highlight that while EU membership is an important determinant in promoting, it is not EU membership that is important, but what it implies. I argue here that the implied benefits from EU membership are decreasingly important, partly because these advantages are less significant as the number of EU members increases. Furthermore, globalisation and the growth of supra-national agreements (particularly those associated with the WTO) mean that several of these benefits are not as unique as they once were. Firms from outside the EU are not forced into EU-based production as often since tariff and non-tariff barriers are fewer. Lastly, the growth of peripheral trade and investment agreements with non-EU members (such as the EU agreement with Mexico) also erode the value of EU membership somewhat (but not completely of course).

Membership of the EU implies two things. First it allows countries that have small domestic markets to expand their de facto market size. Firms located in the EU have access (in theory) to the entire EU. However, as the number of countries in the EU increases, this advantage is shared by at least 25 countries, even more if one includes countries that have preferential access to the single EU market through various lesser forms of trade agreements. Thus this advantage has considerably less value to the candidate and accession countries than it had for the cohesion countries.

Second, membership suggests political, economic and legal stability. This implies an overlap of formal and informal institutions. As with membership, this provides a location advantage vis-à-vis unstable non-members, but not necessarily so compared to non-members who are stable (for instance, some East Asian countries), or relative to other long-standing EU members. Again, the greater the number of countries that are members, the less stability counts as a unique advantage to potential investors.

The point here is that the benefits that accrued from EU membership to the countries that joined earlier are substantially attenuated for later entrants to the EU because of globalisation. First, because global financial, political and economic liberalisation that forms a large part of the globalisation process has 'levelled the playing field' in lowering the risk associated with trade and investment in most parts of the world (Narula 2003). With growing technological convergence, increasing homogeneity of consumption patterns and improved communication and transportation facilities these factors have reduced the costs associated with supplying EU markets from East Asia 
or the Americas. It is worth remembering that a large part of the inward FDI flows from outside the EU prior to 1992 were spurred by the fear of 'Fortress Europe'. These fears have largely proved to be unfounded.

As such, many of the new entrants to the EU are faced with increased competition for FDI not just from other European countries but also from other parts of the world, most notably Asia.

The increased competition for FDI challenges both the cohesion countries and the CEE countries. Many (but not all) of these countries seek to compete on the basis of two primary location advantages: low labour costs and EU membership. As I have discussed above, EU membership is not as much of an advantage in a liberalised, stable and shrinking world where distance does not form as much of a barrier to trade and investment as it once did. For similar reasons, the low cost advantage of these countries has also been dissipated in many cases, particularly where productivity gains in China and other Asian economies have grown (Kalotay 2004). These countries often also have superior technological infrastructure. Spain and Portugal have experienced some displacement of FDI or lost sequential FDI because they have not been able to develop location advantages in knowledge- and capital-intensive activities to compensate for the rising labour costs that have eroded their industrial base in low value adding activities.

\section{FDI and the cohesion countries: policy implications}

In the case of Spain, Portugal and Ireland, I would expect to see some level of displacement to the new members in industries where:

1. Low-cost labour remains the primary reason for location and where the MNE subsidiary has not expanded its original low value adding activities towards knowledge intensive areas in which the domestic economy has a competitive advantage;

2. Where the MNE subsidiary is not embedded through important linkages to other firms in the host economy. When the MNE subsidiary is located close to an important customer or supplier, and proximity is important (e.g., because of just-in-time delivery) it is unlikely that the firm will relocate;

3. Where the sunk costs in the host economy are not high;

4. Where productivity gains have overcome disadvantages associated with rising labour costs. 
In other words, the most obvious long-term solution for cohesion countries is to improve their location advantages in other areas, towards more science-based technological sectors. Ireland has succeeded in doing so with its focus on the ICT sectors (Barry 2004). Spain and Portugal are home to some of the most efficient and productive automotive plants in the world, and are unlikely to lose these operations. However, as Rhys (2004) notes, new plants are more likely to be located in the CEEC countries.

The ICT sectors and automotive sectors are less footloose partly because they are industries in which these host countries are firmly established locations within the major MNEs' global production networks. In each of these locations, furthermore, the MNE affiliates are well embedded in the local economy, and the specialised infrastructure to support these sectors is well developed.

Except where strong domestic sectors and specialised knowledge based clusters existwhether public or private - the CEE countries are unlikely to receive major inflows of FDI that are intended to supply the EU as a single market. Much of the FDI flows to the countries whose primary location advantages are associated with low costs and the presence of 'generic' infrastructure will be those such as food and beverages industries, and service sectors where local presence is essential, or where a scarce resource is cheaply available.

The lesson for most peripheral countries is very much the same: dependence on static and generic location advantages - whether drawing from the development of institutions, infrastructure, stability, or low cost labour - is necessarily short term and short-sighted. The last two decades of increasing liberalisation, falling transportation and communication costs and investment in knowledge-based activities in East Asia has meant that the peripheral EU countries are no longer as attractive (although it should be noted that the lack of strong IPR enforcement in some Asian countries does provide a small window of opportunity). It is axiomatic that as industrial development takes place, the comparative advantage of these countries needs to shift away from low value adding activities to higher value adding activities, which are necessarily science-based.

It is only in those sectors where 'specialised' location advantages associated with higher value adding exist that provide the opportunity to host the 'right kinds' of FDI can host countries benefit significantly from MNE activity in the long run. This 
requires a considerable amount of government interaction and investment. As countries reach a threshold level of technological capabilities, governments need to provide more active support through macro-organisational policies. This implies developing and fostering specific industries and technological trajectories, such that the location advantages they offer are less 'generic' and more specific, highly immobile and such that they encourage mobile investments to be locked into these assets. Many of the CEE countries have the basis for creating such science based location advantages. For instance, Poland has strengths in certain natural and life sciences, as does Hungary in electro-mechanical sectors. The Czech republic has opted to focus on the automotive sector.

There are two points of caution that need to be raised here. First, in pursuing such a strategy, the peripheral EU countries face competition not just from Asia, but also from the 'core' developed economies of the EU which have systematically developed strengths in technology intensive sectors over decades, and can often outcompete weaker, peripheral economies in terms of resources, incentives and opportunities. Nonetheless, there are several niches and gaps in their technological competences that can be effectively exploited by the peripheral economies.

Second, such a strategy requires systematic long-term investment, both in terms of building up the appropriate public infrastructure, and in promoting domestic capacity in both supplier and related activities. Many of the CEE countries have welltrained and skilled work force, but the availability of a large stock of suitably qualified workers does not in itself result in efficient absorption of knowledge, or its efficient use in industrial development. This requires the presence of institutions and economic actors within industry which defines the stock of knowledge in a given location, and the efficient use of markets and hierarchies, be they intra-firm, intraindustry or intra-country. This knowledge is not costless, and must be accumulated over time. Important externalities arise which impinge on the ease of diffusion and efficiency of absorption and utilisation of external knowledge (Narula 2004).

Industrial policy where certain industries are selected for rapid growth by focused investments through intensive development of created assets can and do accelerate economic development. The examples of both the more advanced industrialising countries (such as the Asian NICs) and emerging economies such as Malaysia and Brazil illustrate this. Attracting specialised FDI to a particular sector can alter the sequence of industrial upgrading (Williamson and $\mathrm{Hu}$ 1994), because 
specialised FDI may help improve the created assets associated within a sector (say consumer electronics production). Created assets in this one sector may have significant knowledge flows externalities in another (say micro-electronics design), which in turn may represent significant input to another sector (say software development). But this assumes the presence of a virtuous circle, and the development of appropriate clusters.

FDI-assisted growth requires the capacity to be a 'strategic follower' (Ramos 2000). This requires a systematic understanding of what technological capabilities need to be developed or enhanced, and to seek to actively coordinate potential users with sources of the appropriate technologies. Asian governments that have pursued such a strategy successively have actively sought to identify, acquire and transfer technologies, with government agencies acting as market-makers. Left to their own means, firms have a tendency to be risk averse, and to avoid the financial and technological risk of upgrading their technological assets as long as these provide a reasonable rate of return. This short-term myopia is not unique to firms of any given nationality: governments in Asia - and particularly in Japan, Korea and Taiwan sought to overcome or at least reduce the perceived risk levels by providing subsidised loans and other incentives to domestic firms that restructured their existing operations by adopting new technologies in the products and processes that promoted international best practise.

The countries with the most successful technological upgrading - Korea, Taiwan and to a lesser extent Brazil - allocated subsidies in what Amsden and Hikino (2000) and Amsden (2001) call a 'reciprocal control mechanism'. That is, incentives and subsidies whether to upgrade technologically, promote local content, expand exports or reduce import-dependence were subject to performance standards that were actively monitored, and in Amsden's (2001) words, were 'redistributive in nature and results-oriented' and acted to prevent government failure.

To be sure, upgrading of technological capabilities of domestic firms can no longer be pursued in quite the same way in a globalised world. International competition is a given, and there can be no return to the infant industry model. While a number of CEE countries have had considerable investment in R\&D, a majority of the formal R\&D efforts were conducted by state-owned enterprises and the non-firm sector. While the role of the state must necessarily remain a significant investor in 
innovation, these policies need to be orchestrated with the private firm sector, whether domestic or foreign.

Market forces cannot substitute for the role of governments in developing and promoting a proactive industrial policy. Firms necessarily take a shorter term, profit maximising view because they are largely risk averse. MNEs and unrestrained flows of inward FDI may well lead to an increase in productivity and exports, but they do not necessarily result in increased competitiveness of the domestic sector or increased industrial capacity, which ultimately determines economic growth in the long run. FDI per se does not provide growth opportunities unless a domestic industrial sector exists which has the necessary technological capacity to profit from the externalities from MNE activity. This is well illustrated by the inability of many Asian countries which have relied on a passive FDI-dependent strategy to upgrade their industrial development. It should be remembered that unrestrained FDI inflows often results in 'crowding out' of the domestic sector. FDI and domestic capabilities and a domestic sector need to be concatenated and properly phased if positive results are to be achieved. The lesson here is not that the role of governments should be substituted by the market, but that markets and governments can co-exist. 


\section{References}

Amsden, A. (2001) The Rise of the 'The Rest', Oxford: Oxford University Press.

Amsden, A. and Hikino, T. (2000) 'The Bark is Worse than the Bite: New WTO Law and Late Industrialisation', Annals of the American Academy of Political \& Social Sciences, vol 570, pp. 104-14.

Barry, F. (2004) Prospects for Ireland in an Enlarged EU, World Economy, Vol 27, pp 829-852

Benito, G., B. Grogaard and R. Narula, 2003, 'Environmental Influences on MNE Subsidiary Roles: Economic Integration and the Nordic countries', Journal of International Business Studies, Vol.34, pp.443-56).

Blomstrom, M and A. Kokko, 1997, "How Foreign Investment Affects Host Countries”, Policy Research Working Paper, The World Bank.

Dunning, J. H. and Narula, R. (2004) Multinational and Industrial Competitiveness: A New Agenda, Cheltenham: Edward Elgar

Dunning, J.H. and Narula, R. (1996) (eds), Foreign Direct Investment and Governments: Catalysts for Economic Restructuring, London: Routledge

Kalotay, K. (2004) The European flying geese: new patterns for an old continent? Research in international business and finance, Vol 18, 27-49

Narula, R. (1996). Multinational Investment and Economic Structure, London, Routledge.

Narula, R. (2003). Globalisation and Technology, Cambridge, Polity Press.

Narula, R. (2004). "Understanding absorptive capacities in an innovation systems context: consequences for economic and employment growth”. MERIT Research Memorandum 2004-003.

Ramos, J. (2000) 'Policy Directions for the New Economic Model in Latin America', World Development, vol 28, pp. 1703-17.

Rhys, D.G. (2004) The Motor Industry in an Enlarged EU, World Economy, Vol 27, pp 877-900

Williamson, P. and Hu, Q. (1994) Managing the Global Frontier, London: Pitman Publishing. 